\title{
COUNTERPART FUNDS: THE CANADIAN EXPERIENCE IN LATIN AMERICA AND THE CARIBBEAN
}

\section{Susan Gardiner}

Counterpart funds can offer many development opportunities if used effectively but can also hamper and distort development if improperly used. This article reviews the rationale for the establishment of counterpart funds and discusses the opportunities, and lessons learned. The Canadian financed counterpart fund in Peru and the Canadian supported Bolivia Social Fund are both discussed. The discussion reflects on Canadian aid policy and programming in the Americas between 1988 and 1990 .

\section{CHARACTERISTICS OF THE AMERICAS REGION}

During the 1980s, Latin American countries were faced with an onerous debt burden - one-third of Latin America's export earnings were devoted to paying interest on this debt. Most of the countries in the region implemented economic reforms which in the first instance resulted in considerable hardships for certain segments of the population. This served to aggravate the historically extreme social inequities existing in Latin America. In tightening expenditures, governments were forced to further reduce spending in such key areas as basic education, health, housing and protection of the environment.

Most Latin American and Caribbean governments were receptive to the creation of counterpart fund mechanisms for support of poverty alleviation programming. Government support can be attributed to a number of factors, including: public institutions in many countries were recognized as weak due to resource constraints and/or a history of military governments; donor funding to Latin countries was relatively small compared to the size of the economies; certain segments of the population could best be served through non-governmental channels (particularly indigenous groups); and there was an urgent need to mitigate the negative effects of structural adjustment on vulnerable groups.

\section{CANADIAN AID IN LATIN AMERICA}

The Canadian International Development Agency's (CIDA) policy on counterpart funds does not require programmes to generate funds. If funds are generated then the rationale for doing so must be provided and approved in the country programme framework (i.e. a five year planning document) and appropriate financial and administrative safeguards must be followed.

The objectives of the Canadian aid programme in the Americas from 1988 to 1990 were to support structural adjustment efforts of their economies, alleviate poverty through support of income generating activities and provision of social services, and support human resource development and institutional strengthening. Canadian aid to the Caribbean and Latin America in fiscal year 1989/90 (non-inclusive of imputed multilateral flows) was approximately $\$ \mathrm{C} 272$ million (CIDA, 1990) and was completely grant financed.

Promotion of human rights, pluralistic societies, the development and empowerment of human resources and the participation of women were viewed by Canadian aid policy-makers as integral to alleviating poverty. These objectives could not be met exclusively through central governments but required the participation of local governments, non-governmental groups and the private sector.

\section{COUNTERPART FUND MECHANISMS}

During the period 1988 to 1990 , Canadian programming in the Americas region established counterpart fund mechanisms in the following programmes: Peru, Bolivia, Ecuador, Colombia, Jamaica, Guyana, Haiti, El Salvador, Honduras, Costa Rica and Nicaragua. Total counterpart funds generated in $1990 / 91$ were \$C53.0 million.

The mechanisms, the degree of control exercised by Canada and the use of the funds varied considerably. Responsibility and control of counterpart funds depended on the countries' development situation, the recipient country's adherence to sound economic and social policies and respect for human rights, and the capability of the recipient government or local nongovernmental organizations (NGOs) to deliver poverty alleviation programmes.

For Jamaica and Costa Rica, counterpart funds were programmed only through the government budgetary process. This was based on the countries' demonstrated commitment to the implementation of sound economic 
policies. The counterpart funds generated in Honduras were allocated through the government's budgetary process to cover local cost financing of CIDA funded projects and for transfers to a government social investment fund.

In Guyana, balance of payments support was provided in conjunction with the implementation of a stabilization programme. A portion of the counterpart funds was allocated to the consolidated revenue funds to support the government's Public Sector Investment Programme. A portion was allocated to a counterpart fund, managed by a Canadian NGO and designed to implement programmes targeted at the poor. For Peru, lines of credit were provided despite the fact that Canada did not, at that time, support the economic policies of the government. Counterpart funds generated were tightly managed and were utilized to support the productive sectors and high social impact projects.

In Colombia and El Salvador funding was nonbudgetary and was programmed through a nongovernmental mechanism. Funds generated by CIDA's programme in Bolivia were allocated to the Bolivian established Social Fund and also to a proven NGO consortium.

In some cases, counterpart funds were established in countries that did not have a programme with the IMF or the World Bank, such as Colombia and Peru. In other cases, at the time of implementation of stabilization programmes, Canada believed that insufficient resources were allocated to mitigate the hardships imposed on certain segments of the population and provided off-budgetary support for poverty activities. In all cases, Canada consulted with the Bank to ensure that funding activities were not inconsistent with Bank promoted policies.

In those instances where counterpart funds were offbudgetary, funds were deposited directly into a private project account. The funds were spent in accordance with criteria set out in a Memorandum of Understanding between Canada and the recipient government and were normally channelled through non-governmental organizations or the private sector to local community associations/governments. In many countries in Central and South America, this was the only means to reach the poor indigenous populations who had an inherent mistrust of working with the central governments.

\section{CANADIAN FINANCED COUNTERPART FUND IN PERU}

When Peru unilaterally refused to honour its debt obligations in 1985, and attempted to nationalise banks and financial institutions, Peru's cooperation with bilateral and multilateral donors and financing institutions deteriorated or was halted. Under these circumstances, CIDA saw its bilateral aid programme circumscribed by growing security problems and the need to respect arrangements of the international financial community. Canada decided to continue aid delivery to the poor so as not to double penalise those who would suffer from a worsening economic situation. CIDA therefore developed a line of credit and counterpart fund programme that would:

i) provide balance of payments support by making available commodities and equipment under normal commercial conditions, to viable and solvent economic sectors (those able to pay, invest and repay debts);

ii) ensure that the full value of the aid was channelled to a Fund with no allowance for subsidies or any diversion to budgetary support; and,

iii) be consistent with CIDA's developmental strategy in regard to self-sustaining, productive and environmentally safe activities that assist the poorest segments of the country.

Funds generated from lines of credit and food aid in 1990/91 were approximately \$C11.5 million. The lines of credit were primarily commercial in nature and not developmental. These lines of credit were made conditional on the Government's agreement to the generation of counterpart funds which would be managed through an independent private and legal entity which had administrative and operational autonomy.

The counterpart fund mechanism provided for the establishment of a Development Foundation to ensure independence from governmental interference, the provision of a Canadian technical assistance unit to the foundation, and safeguards to protect the monetary value of the funds.

The independence of the Development Foundation was seen by all parties involved, particularly the Government of Perru, as critical to the efficient and effective delivery of development projects and programmes at the time of its establishment. The General Counterpart Fund Canada/Peru (GCFCP) was successful in establishing its independence. It had a five-member Board of Gover nors, of whom two were Canadian officials, and a secretariat managed by two co-directors. The staff comprised thirteen individuals. Consultants were also used. A Canadian Technical Assistance Unit was established to provide managerial, technical, and administrative support to set up GCFCP and develop the Secretariat. Its establishment was seen by the Board and Peru, as crucial to the existence of the Fund to act as a credible and efficient institution in Peru. 
Collecting and accounting for the funds generated by the lines of credit was the responsibility of the GCFCP Secretariat financial manager. The Canadian Embassy in Lima was responsible for ensuring that counterpart funds were paid. With the agreement of the Government of Peru, payments to the CGFCP were made in local currency, but deposited in a US dollar denominated bank account which generated interest a critical factor in overcoming the loss of purchasing power of the GCFCP. All withdrawals were in local currency.

An operational evaluation of GCFCP reported that a majority of projects were successful in achieving expected results. In the informal, small business and health and welfare sectors, the projects appeared to have a high social impact at the micro and local level. The impact of projects will take longer to measure for the agriculture and disaster recovery sectors. The Fund was particularly successful at financing projects which reached the poor population living in zones affected by insurgency guerilla activities (World Bank 1990).

\section{THE CASE OF BOLIVIA - CREATION OF A SOCIAL FUND}

The Government of Bolivia established the public bypass agency, the Fondo Social de Emergencia (FSE) in November 1986 , as a temporary emergency response to rapidly deteriorating social conditions caused by a severe economic crisis and a drastic adjustment programme. The FSE Director reported directly to the President, which enabled the fund to achieve a high degree of autonomy in its operations.

A consortium of donors including Canada (through counterpart fund generation), Belgium, Germany, Italy, IBRD, IDB, UNDP and the OPEC Fund, funded the FSE to a total of US $\$ 194$ million. Following initial success through the generation of small scale temporary employment projects, the FSE expanded rapidly.

In Bolivia, the NGOs like church groups and community organizations proposed projects for central social fund approval with private local contractors implementing them. Zuckerman (1990) suggests that this decentralized, grassroots approach:

- ensured that neither donors nor government agencies determined project content (as has frequently been the case in conventional projects);

- maximized incentives to prepare and maintain highquality community projects;

- reached remoter and poorer communities; and

- entailed lower-cost administration and technologies.
Four major categories of projects were financed including: Social assistance (10 per cent); Social infrastructure (42 per cent); Economic infrastructure (42 per cent); and Production support ( 6 per cent). In 1989 FSE was responsible for about 80 per cent of all public investment in health and about 75 per cent in education. The FSE has been heavily supervised and studied by the donor community as well as its own staff.

As a result of the FSE projects, total disbursements exceeded US $\$ 125$ million. It is estimated that over 1.4 million people benefited and 547,000 personmonths of direct employment were created. The FSE will be disbanded in 1991 and replaced by a Social Investment Fund which will finance projects designed to support sustainable development initiatives.

\section{LESSONS FROM CIDA EXPERIENCE IN LATIN AMERICA AND THE CARIBBEAN}

The impact for CIDA as a result of counterpart fund programming is illustrated in the following policy and programming areas:

i Structural Adjustment - CIDA has been able to support governments' efforts to implement macroeconomic reform, while at the same time ensuring that additional funding has been provided to mitigate, to some degree, the negative impact of reform on poorer seginents of the population.

ii Poverty - Canadian programming in the Americas utilizes a number of different mechanisms for implementing programming which directly benefits and empowers the poor. Such activities tend to have high local costs - counterpart fund generation is probably the most efficient delivery mechanism for providing local cost financing while meeting Canadian aid requirements.

iii) Canadian Administration Requirements through the provision of internationally competitive goods procured in Canada, CIDA can meet its tied aid requirements, provide balance of payments support to the recipient government, and channel counterpart fund resources for poverty activities through local nongovernmental organizations (NGOs) or local governments. Providing lines of credit is much less administratively intensive for CIDA than regular programming, which places high demands on CIDA staff, from the selection and contracting stage throughout project implementation.

iv) Reducing Distortions - the generation of funds can reduce the discretion of the government and distort the government's investment priorities. To minimize distortions (when Canada agrees with the policies of the country) Canada either provides aid in support of IMF programmes or stipulates that the counterpart funds finance projects which are supportive of the 
government's stated priorities. In addition, most Fund mechanisms are required to have a representative of the recipient government on the project selection committee.

v) Coordination - there must be coordination of donor counterpart funds, particularly in countries which rely heavily on development assistance, such as Guyana.

vi) Reliable Financing - to provide reliable financing of projects, there should be assured continuity in the delivery of goods and commodities, preferably at regular intervals throughout the year. For most countries, the counterpart funds generated from several project sources (including food aid) are consolidated into one Fund mechanism.

vii) Accounting of Funds - administratively, CIDA has learned that it is important that a mechanism for collection and disbursement of funds must be operational when generation of funds commences to avoid an accumulation of funds and the associated inflationary impact. Responsibility for the deposit and accounting of funds (i.e. timing, appropriate exchange rates, etc.) must be clearly spelt out in the agreement between governments and specify that funds are to be credited without delay to a specified independent interest-bearing account at the full CIF value, before subsidies or deductions.

viii) Policy Dialogue - CIDA has also learned that the sustainability of poverty activities is dependent on government implementation of social policy reform designed to reduce extreme income disparities. Canada has had minimal success in utilizing counterpart funds to affect recipient country budgetary allocations, in part due to the limitations of donors in carrying out the economic and budgetary analysis necessary to negotiate conditionality and monitor adherence. In one or two instances, recipient countries have advised Canada not to utilize the budgetary process to channel monies to non-governmental organizations because of the difficulties of having the monies released.

Non-budgetary support provides leverage to ensure additionality of poverty alleviation activities. The danger is that governments will not undertake required policy reforms aimed at strengthening public sector agencies and addressing income inequities. Coordination with the donor community is important to ensure follow-up or parallel social sector adjustment operations containing more comprehensive sector policy reforms.

\section{CONCLUSION}

From the donor perspective, the establishment of counterpart funds for poverty activities can provide insurance, a form of social equity conditionality and a cost effective means of targeting the poorer segments of the population.

While central governments must establish the appropriate framework for development, other levels of government, non-governmental institutions and the private sector have an equally important role to play in development. Counterpart funds offer a valuable mechanism for supporting the 'other' players.

Nevertheless, counterpart funds can be counter productive if not properly managed. If donors choose to exercise control over the allocation of resources they must ensure that counterpart fund expenditures are planned in advance of fund accumulation and that the Fund mechanisms are more efficient and/or effective than the government at reaching target groups.

\section{REFERENCES}

Audet, J. and Bade, M., General Counterpart Fund CanadaPeru, Operational Review, Mauricio Antezane Villegas, June

CIDA, 1990, Annual Report 1989-90, Minister of Supply and Services Canada, Ottawa, Canada
World Bank, 1990, World Development Report 1990, Oxford University Press, Washington, DC, June

Zuckerman, E., 1990, Social Funds in Latin America. Where do we stand?, Plans and Programmes Department, InterAmerican Development Bank, Washington, DC, October 